\title{
Fatalism, Foreknowledge and Free Will
}

\author{
Madhu Mangal Chaturvedi*
}

\begin{abstract}
Summary
This paper argues that the concept of divine Foreknowledge is not inconsistent with the denial of fatalism. From the finite perspective of us humans, it might appear that fatalism necessarily follows from the idea of an all-knowing God. However, from an all-knowing and all-powerful God's point of view, assuming that such a Being exists for the sake of argument, divine Foreknowledge does not necessarily imply fatalism for us. Moreover, to deny that an all-knowing God could be wrong about our future is to make an inconsistent claim. Divine Foreknowledge means that God has infallible Knowledge about our future, and that must be fixed. However, I argue that the denial of fatalism is not inconsistent with God's Omniscience when combined with some of His other attributes. For instance, a combination of divine Foreknowledge, Omnipotence and Free Will. In other words, God knows the future, but He is not limited to knowing the same future. For God can will the future to be quite different from what He knows it to be. That is to say, with respect to us, God's Free Will is consistent with the negation of fatalism. The last claim also implies that there is space for human free will in between God's Foreknowledge and Free Will.
\end{abstract}

Keywords: fatalism; Free Will; divine Foreknowledge; Omniscience

\section{Introduction}

»There is in God power, which is the source of everything, then knowledge, which contains the detail of ideas, and finally will, which brings about changes and products in accordance with the principle of the best « (Leibniz, Monadology, $\S 48$; Strickland, 2014, 23)

Fatalism is the thesis that every event that occurs in this world is fixed. That is, there are no open possibilities. Whatever happens, whatever has happened, and whatever will happen, is already fixed (Taylor, 1962; McArthur, 1977). Peter van

* Madhu Mangal Chaturvedi, Ph.D., Assistant Professor, School of Philosophy and Culture, Faculty of Humanities and Social Sciences, Shri Mata Vaishno Devi University. Address: Sub-Post Office Katra, Jammu and Kashmir (UT), India - 182320. ORCID iD: https://orcid.org/00000003-3884-4244. E-mail: vijai.madhu@smvdu.ac.in 
Inwagen $(1983,23)$ defines fatalism as the thesis that »it is a logical or conceptual truth that no one can act otherwise than he does; that the very idea of an agent to whom alternative courses of action are open is self-contradictory«. If fatalism is true then, human beings do not have free will. To have free will means that an agent could do something other than what $\mathrm{s} /$ he did. Free will is not just the power of an agent to do $\mathrm{X}$ at the time $\mathrm{T}$ but also not to have done $\mathrm{X}$. As A. J. Ayer $(1982,15)$ puts it: »When I am said to have done something of my own free will, it is implied that I could have acted otherwise, and it is only when it is believed that I could have acted otherwise that I am held to be morally responsible for what I have done «. For instance, if fatalism holds, then I could not have done anything else but write these lines that I am writing now. I do not have many choices. My feeling that I am doing whatever I am doing right now out of my own free will is just an illusion. Whatever I think about my free will, I could not have done other than write these sentences that I was fated to write. It was my fate to do precisely that which I am doing right now. Even if I think that I might have done something else, it was also pre-decided that such a thought would occur at that time. It is not within my powers to think or desire anything else at a given moment. In other words, I do not have free will since everything that is happening right now, everything that has ever happened in the past, and everything that will ever happen in the future is fixed and will be necessary as it is.

Now among many arguments for fatalism, the argument from divine Foreknowledge is the most interesting. It is interesting because it neatly presents the equation between fatalism, divine Foreknowledge and free will. The argument has the form of a hypothetical syllogism. According to the divine Foreknowledge argument, if divine Foreknowledge implies fatalism, and fatalism implies the denial of free will, then divine Foreknowledge also implies the denial of free will.

Divine Foreknowledge $\rightarrow$ Fatalism

Fatalism $\rightarrow \sim$ Free Will

Divine Foreknowledge $\rightarrow \sim$ Free Will

The argument from divine Foreknowledge for fatalism claims that if there is an omniscient God, then, by definition, He knows all facts in advance: past, future and present. This reasoning implies that, whatever happened, what is happening, and what will happen in the future is fixed. This inference is consistent with the concept of Omniscience, which is an attribute of God. An omniscient God cannot have false knowledge. Now, there seems to be a conceptual problem in denying fatalism and holding the omniscience of God. If God is omniscient, then fatalism is true. Once we accept that there is an all-knowing God for the sake of argument, then we cannot deny fatalism without contradiction. The following set of statements cannot be true simultaneously:

A 1) God is omniscient.

A 2) God can be mistaken about the future.

Similarly, the following set of statements cannot be true simultaneously:

B 1) God cannot be mistaken about the future.

B 2) Fatalism is false. 
If God foreknows what the future will be like, then there are no open possibilities, and the future is fixed. The future cannot be different from what God knows it to be. Here enters free will. If God knows what I will do tomorrow, I have nothing in my power to prove God's Knowledge wrong. That is to say, I will do precisely that which God already knows I will be doing. In other words, if God has Foreknowledge, then I have no free will (Pike, 1965). For instance, if God knows I will read the paper on divine Foreknowledge written by a particular philosopher between the given period, I will do nothing else but read the paper by this philosopher during that specific period. I cannot even choose to change the title or the author of the paper and, indeed, not the time at which I will be reading it as believed by God. If I can change any one of these things, I have the power to prove God's Foreknowledge wrong. In other words, if God has Foreknowledge about future events, including my own decisions, then I really do not have a choice. In other words, divine Foreknowledge entails fatalism and denial of free will.

One way to solve this challenging equation between fatalism, Foreknowledge, and free will, is to explain how the Omniscience of God is not inconsistent with the possibility of an alternate future and hence with free will. The challenge is to define foreknowledge without falling into fatalism. Let us call this fatalism challenge. One of the ways to handle the fatalism challenge is to redefine foreknowledge so that it keeps the possibility of an alternate future open and does not undermine God's Omniscience. Here again, we can see two different strategies. The first one is rather direct, and its focus is on the nature of divine Foreknowledge itself. The question addressed in this strategy is 'How does God really know?' Does God know by believing or by perceiving? The idea is that if God knows by believing something is the case, only then can we say that He is mistaken (Conee \& Sider, 2005). The other strategy is indirect. In this indirect approach, the focus is on the nature of facts, as in the famous distinction between "hard" and "soft" facts (Fischer, 1983). Hard facts are unalterable. However, if facts about human actions are soft facts that can change, perhaps human freedom and divine Foreknowledge are incompatible. In the next section (1), I discuss these two strategies.

\section{Responses to the fatalism challenge}

In response to the fatalism challenge, some philosophers have tried to adopt a compatibilist approach. According to the compatibilist approach, we can interpret divine Foreknowledge as consistent with human freedom. As discussed above, the direct strategy is to reinterpret divine Foreknowledge, without compromising free will. Let us call it knowledge strategy, in contrast, to the strategy of distinguishing divine Foreknowledge into hard and soft facts, which we shall call the fact strategy. 


\subsection{The knowledge strategy}

The basic idea of the knowledge strategy is to reinterpret divine Knowledge as compatible with free will. In other words, even after granting that God has Foreknowledge of future events, it is possible to maintain that humans have the freedom to choose a different course of action. For example, even if God foreknows that an agent, $\mathrm{A}$, will do $\mathrm{X}$ at time $\mathrm{T}$, still $\mathrm{A}$ can do $\mathrm{X}$ or refrain from it without implying that God's Foreknowledge is fallible.

For instance, Davis $(1979,314)$ distinguishes 'inferential foreknowledge' and 'future vision'. God has "inferential foreknowledge" when He »deduces or infers what is going to happen in the future by extrapolating from what is happening in the present by use of causal laws (or by some other intellectual procedure). Where events are brought about and made inevitable by sufficient antecedent conditions, and where God inferentially knows that they will happen, their freedom (as defined earlier) is ruled out «. Such inferential Foreknowledge is different from Foreknowledge through a future vision in which human actions are not dependent on sufficient antecedent conditions. Suppose God's Foreknowledge is like knowing the future visually. In that case, He cannot infer what the person will do since whatever choices the person makes will be compatible with the presence or absence of such conditions. Therefore, in future vision, God's Foreknowledge is more like a direct observation of events as an indifferent witness than someone who foresees things happening due to sufficient causal conditions. God's Foreknowledge as future vision rules out any causal or nomologically necessary relation between God's Foreknowledge of events and humans choices. However, in the latter case, God's Foreknowledge has a necessary causal link between the events from which God infers future events. The upshot is that if God can infer the future, then it is necessary, and what He cannot infer is contingent. Therefore, human actions are free since God's Knowledge of them is not inferential.

Here, it is crucial to note that divine Foreknowledge is not separate from Omniscience. As La Croix (1976) has argued, having Knowledge of all events is a necessary condition for being omniscient. Since Foreknowledge means having Knowledge of future events, an omniscient being must also have Foreknowledge. »To be omniscient God must know about all events. So, if it is false to ascribe to God the knowledge of some future event or other, then it would also be false to say of Him that he is omniscient « (La Croix, 1976, 366). In other words, without Foreknowledge, God cannot be called an omniscient being. Moreover, according to La Croix, it would seem that, unlike Omnipotence, Foreknowledge and Omniscience are not dispositional properties of God. Whereas being omnipotent does not necessarily mean performing the acts, having Foreknowledge means not only having the ability to know future events but actually knowing them. The non-dispositional nature of Foreknowledge means there must be at least one future event which, while being in the future, is among the objects of God's Knowledge (La Croix, 1976, 366). According to La Croix, if one assumes that future events are in principle knowable, then divine Foreknowledge is an aspect or 
a function of Omniscience. Thus, he attributes the property of 'Omniprescience' to God (La Croix, 1976, 366). ${ }^{1}$

Thus, 'Omniscience' means knowing everything that has happened, is happening and will happen at all times. Or, as Zagzebski $(2013,310)$ puts it, »a being A is omniscient just in case A knows the truth value of every proposition. Assuming that every proposition is either true or false, then for every proposition $p$, either A knows p is true, or A knows $\mathrm{p}$ is false «. This definition of Omniscience implies that an omniscient being, such as God, will also have Foreknowledge of the truth values of all the propositions describing future events. However, suppose there are such future events that are undecided and unpredictable because someone with free will has not chosen as to whether to bring them about or not. In that case, no propositions describe those future events and hence no truth values to be known even by God. »An omniscient God can know all there is to know, but this does not include what is not possible to know. It is in this sense that future free acts cannot be known by God, for there is nothing yet to be known. Freedom implies that future actions are not predictable (Ramberan, 1985, 485).

So, according to Ramberan $(1985,485)$, »God's omniscience does not entail 'foreknowledge' and hence can be compatible with human freedom.« Ramberan tries to resolve the problem of incompatibility between God's Foreknowledge and human freedom by arguing that God's Foreknowledge and omniscience are mutually exclusive concepts. He also emphasizes that it is logically impossible for God to foreknow events 'caused' by human free will. Thus, there is no conflict between human freedom and God's Foreknowledge, as it does not apply to the case of free actions. Moreover, knowledge of future human actions is not necessary for God to be omniscient. Free human actions are precluded from being in the domain of knowledge, even of an omniscient God. God cannot know what a human being will do before the action is performed (Ramberan, 1985, 487).

Now, if we say that KGP (God knows that P) at time T, then there are three possibilities with respect to the temporal relation between the occurrence of $\mathrm{P}$ and God's knowledge of P at T:

1. KGP is simultaneous with the occurrence of $\mathrm{P}$ at time $\mathrm{T}$

2. KGP at time $\mathrm{T}$ where $\mathrm{P}$ occurs in future at time $\mathrm{T}+1$ and $\mathrm{T}<\mathrm{T}+1$

3. KGP at time $\mathrm{T}$ after $\mathrm{P}$ has already happened at time $\mathrm{T}-1$ and $\mathrm{T}-1<\mathrm{T}$

As far as God's Omniscience is concerned, it cannot be simultaneous with the occurrence of events. Here, we can make a distinction between diachronic and synchronic simultaneity. By diachronic simultaneity, I mean that God already knows all events across all times - past, present, and future at any given moment. God knows what happened yesterday, what is happening today, and what will happen tomorrow, and He knows it at this very moment. On the other hand, synchronic simultaneity would imply that God knows everything that is happening at

1 Although La Croix (1976) aims to show that "divine foreknowledge, interpreted in a plausible way and taken together with certain other doctrines about the nature of God, is inconsistent with divine freedom" (Quinn, 1978, 219). See Quinn (1978) who argues that La Croix's arguments fail to show that divine foreknowledge is incompatible with divine freedom. 
any moment across all space. Certainly, diachronic simultaneity is much stronger than synchronic unity. However, if God's Knowledge of an event is simultaneous with the occurrence of that event, then it means that God will have to wait for that event to occur to know of it. Although this interpretation would be pretty favourable for defending the human freedom of will, this effectively rules out Foreknowledge as included in Omniscience. Moreover, God's Omniscience does not allow for post facto knowledge. Therefore, we can ignore possibilities (1) and (3). It is the possibility (2) that creates the problem of free will vis-à-vis God's Foreknowledge. If 'God knows that P' at a time before the occurrence of $\mathrm{P}$, then the non-occurrence of $\mathrm{P}$ will render God's Knowledge about $\mathrm{P}$ false.

The knowledge strategy is fraught with difficulties. All our attempts to interpret God's Foreknowledge to secure free will land us in anomalies. If God's Foreknowledge is like perception, it will be a case of possibility (1) discussed above and will face the same difficulty. Similarly, to argue that the Knowledge of future human actions is not necessary for Omniscience is to weaken the very concept of Omniscience and divine Foreknowledge.

\subsection{The fact strategy}

The other approach to resolve the dilemma between Foreknowledge and free will has been to admit that God has Foreknowledge of what a human agent will do in the future. Still, such Knowledge is a "soft fact" and thus does not undermine human freedom. The "soft fact" is contrasted with "hard facts". This strategy is known as the Ockhamist approach. The Ockhamist strategy tries to resolve the incompatibility between divine Foreknowledge and human freedom by distinguishing " "hard' and 'soft' facts about the past". Their claim is that »while hard facts about the past are indeed fixed in the intended sense, this is not always true of soft facts about the past. Since the Ockhamist thinks that God's foreknowings of present and future human actions are soft facts about the past which are not fixed, the Ockhamist believes that he can allow for human freedom « (Hoffman \& Rosenkrantz, 1984, 419). ${ }^{2}$

The distinction between "hard" and "soft" facts about the past is that »the hard facts are fixed while the soft facts need not be fixed « (Fisher, 1983, 68). The idea is that if at time T-1, God knows that at time $\mathrm{T}+1$, "a human agent A will do $X$ ", where $T-1$ is before $T+1$, then at a time $T+2$ later than $T+1$, the occurrence of $\mathrm{X}$ is an unalterable fact consistent with God's Foreknowledge. However, there might be a time $\mathrm{T}$, between $\mathrm{T}-1$ and $\mathrm{T}+1$, at which it might be possible to bring about that agent $\mathrm{A}$ would refrain from doing $\mathrm{X}$ without contradicting God's Foreknowledge. In other words, God's belief at T-1 that "A will do X at time $\mathrm{T}+1$ ” is a soft fact at time $\mathrm{T}$ with respect to $\mathrm{T}+1$.

2 For more detailed discussion on the distinction between hard and soft facts and whether this distinction can solve the problem of inconsistency between divine foreknowledge and human freedom see Hasker (1988 and 1989). 
However, this strategy, too, does not seem to work. Intuitively speaking, any past event is fixed by being in the past. Since God's Foreknowledge implies that God already knows what is going to happen, then regarding a future event, God's Foreknowledge is in the past too. God's Foreknowledge of future events is in the past - an unalterable fact.

\section{Human freedom: in between divine free will and foreknowledge}

Even for a staunch theist, a world without human freedom would be unbearable. And although the theist might be ready to sacrifice human freedom in favour of an all-knowing and all-powerful God, the price of this denial will be to have faith in an Evil God responsible for all the sins committed by human beings in the absence of their freedom. Thus, the denial of human freedom in favour of God's Foreknowledge might not be an option. However, there should be a way to reconcile human freedom with divine Foreknowledge in the face of the fatalism challenge.

I suggest that human freedom may remain intact and supported by various divine attributes other than and including Foreknowledge. Suppose we try to resolve the incompatibility of human freedom with divine Foreknowledge in isolation from other divine attributes such as Omnipotence and Free Will. In that case, there will always be an irreconcilable gap between the two. However, we can salvage human freedom by putting it in the nexus of various divine attributes, including Foreknowledge. Now, to discuss all the divine attributes will be beyond the scope of this paper. Therefore, I shall take the three major and most relevant attributes here, viz. Foreknowledge, Free Will, and Omnipotence and try to show that the three together are compatible with human freedom.

By divine Foreknowledge here, I mean the power of God to know the future. The Free Will of God means that God has the power to choose to do something and also to abstain from doing it. Omnipotence is God's power to do anything He wishes. Now, divine Free Will and Omnipotence are complementary to each other. God can be said to be omnipotent only when He can freely choose to do something or not do it. Moreover, God cannot be said to have Free Will if it is not within His powers to decide to do something or abstain from it. In other words, Free Will implies Omnipotence and vice versa. Furthermore, Omnipotence and divine Foreknowledge too are logically equivalent. From God's point of view, reality and knowledge of reality are not two different things. God knows reality and what God knows is reality. In other words, Omnipotence is the function of divine Foreknowledge with respect to future events. To create anything, God does not have to do anything other than to have Knowledge of it. If God knows that an event $\mathrm{X}$ will happen tomorrow, then its occurrence is just a manifestation of God's foreknowing it.

When we put these three together, we can see that God knows future events. In virtue of His knowing the future, His Omnipotence ensures that the event in question occurs without contradicting His Knowledge. However, when the future 
event is the choice made by a human agent, God foreknows the agent's choice. His Omnipotence brings about the event that is consistent with His Foreknowledge. However, since God has Free Will, God can will a different future depending upon the choice made by the human agent. God's Free Will is the essence here.

God's Foreknowledge of future events does not imply fatalism, i.e. future events are fixed. To allow this is to confine divine Free Will. From God's point of view, future events are not fixed because God could will them to be different. God's Free Will also means that God's Knowledge is neither cognitive, as a belief, nor is empirical, like perception. The epistemological problems that we usually associate with human knowledge do not arise in the case of God. God does not have to know any fact through some medium. There is a problem with human knowledge because ours is not a direct knowledge of reality. However, God does not know reality in the ordinary sense; instead, what God knows is reality. For instance, God does not form beliefs about reality. For, if we say God forms beliefs about reality, we put a severe limitation to God's Omniscience. ${ }^{3}$ Since beliefs are propositional attitudes and have the "mind to world-direction of fit", God's beliefs will have to correspond to reality to be true rather than the other way around. (Unlike other propositional attitudes such as desire, which have the "world to mind-direction of fit". My desires come true when the world conforms to them. I might desire rain, and the desire will be true only if it is actually raining. $)^{4}$ Since beliefs could be true or false, God cannot know by believing. Even if we claim that God holds only true beliefs, still we compromise God's Omniscience and Omnipotence. Therefore, God knows what will be in the future, but He is not constrained by His Knowledge of the future such that He cannot allow for a different future. Human actions are free in the sense that God's Knowledge of the future is not fixed. God has Free Will too.

\section{The problem of inconsistent divine attributes}

One possible objection to the proposed thesis of the paper could be that the divine attributes of Omniscience and Free Will are inconsistent. If God has to will a different future depending upon what a human agent decides to do at any future time, then this simply means that God does not have Foreknowledge. This inconsistency is a submission that God failed to foresee what exactly an agent was going to decide. Moreover, if we say that God foreknows two possible worlds such that, in one of them the agent will do $\mathrm{X}$ whereas in the other the agent will do Y, then also God does not really foreknow which one of the possible worlds will be actualized because He has to rely on the outcome of an agent's deliberation to choose one course of action over the other. So, the problem boils down

3 See Alston (1986) for arguments in support of view that beliefs are not constituent of divine knowledge.

4 See Humberstone (1992) for discussion of direction of fit. 
to this dilemma: either God foreknows what a human agent will do or does not know what a human agent will do until s/he has made a choice. In the former case, the agent does not have free will, and in the latter case, the agent has free will, but God does not really have Foreknowledge. It certainly seems we are back to square one. However, it might not be so.

The point is that there seems to be some space for human freedom between divine Foreknowledge and divine Free Will. Instead of reconciling human free will with God's Foreknowledge or preferring one over the other, one can see that human free will is consistent with God's Free Will. Saying that God has the Free Will to create an alternate future depending upon what choices a human agent makes is not necessarily limiting God's Foreknowledge vis-à-vis human free will. Rather, it is an acknowledgement of God's attributes other than Foreknowledge. God foreknows what you will do, but if you change your mind, you do not prove God wrong because God has the free will and power to create an alternate future consistent with your choice.

\section{Conclusion}

In this paper, I have argued that the denial of fatalism is not inconsistent with divine Omniscience and that divine Omniscience is not in conflict with human free will. The thesis of fatalism is that there are no open possibilities at any point in time and divine Foreknowledge also implies the same. However, let's consider divine Omniscience in combination with other divine attributes, such as divine Free Will and Omnipotence. We can say that God is capable of willing a different future in line with the free choices made by the human agent. We can deny fatalism and keep free will vis-à-vis God's Foreknowledge, Free Will, and Omnipotence. God knows the future in advance, but He is not limited to knowing a fixed future. Rather, God can will the future according to the choices made by the human agent. If the objection is that if God has to will a future different than the one foreknown to Him, then God does not have Foreknowledge. In response to this objection, I can only say this much. To be able to keep God's attributes such as Foreknowledge, Free Will and Omnipotence intact along with a place for human freedom is much more satisfying than rejecting divine Foreknowledge altogether or becoming a fatalist. In addition, God's Foreknowledge of events involving human agents who have the power to choose their course of action consciously cannot be treated like other natural events that are absolutely fixed in agreement with God's Foreknowledge of them. After all, God made man in his own image.

One might object that what God knows at T1 about T2 cannot be changed without contradicting God's Omniscience. However, this is not the case. God knows at $\mathrm{T} 1$ what will happen at $\mathrm{T} 2$, but as far as human actions are concerned, God can know different possibilities at $\mathrm{T} 2\left(\mathrm{~T}_{2} \mathrm{P}^{1-\mathrm{n}}\right)$.

There is a much deeper point about God's ability to create and manifest the world without putting self-restrictions on His various attributes. As Alan Watts 
put it, »since no art can be accomplished which does not set itself certain rules and limitations. A fully infinite and boundless God would have no limitations and thus no way of manifesting power or love. Omnipotence must therefore include the power of self-restriction - to the point of forgetting that it is restricting itself and thus making limitations seem real« (Watts, 1977, 10). Similarly, God must have the power to restrict His Omniscience so that it does not necessarily stop Him from willing a different future for human agents.

\section{Bibliography}

Alston, William (1986). Does God Have Beliefs? Religious Studies, 22, 287-306.

Ayer, Alfred Jules (1982). Freedom and Necessity. In G. Watson (ed.), Free Will (pp. 1523). New York: Oxford University Press.

Conee, Earl; Sider, Theodore (2005). Riddles of Existence: A Guided Tour of Metaphysics. Oxford: Clarendon.

Davis, Stephen T. (1979). Divine Omniscience and Human Freedom. Religious Studies, 15(3), 303-306.

Fischer, John Martin (1983). Freedom and foreknowledge. Philosophical Review, 92(1), 67-79.

Hasker, William (1988). Hard Facts and Theological Fatalism. Noûs, 22(3), 419-436.

Hasker, William (1989). God, Time, and Knowledge. Ithaca NY: Cornell University Press.

Hoffman, Joshua; Rosenkrantz, Gary (1984). Hard and Soft Facts. Philosophical Review, 93(3), 419-434.

Humberstone, I. L. (1992). Direction of Fit. Mind, 101(401), 59-83.

Inwagen, Peter van (1983). An Essay on Free Will. Oxford: Clarendon.

La Croix, Richard R. (1976). Omniprescience and Divine Determinism. Religious Studies, 12(3), 365-381.

Leibniz, Gottfried Wilhelm (2014). The Monadology. Llyod Strickland (Trans.) Leibniz's Monadology: A New Translation and Guide. Edinburgh: Edinburgh University Press.

McArthur, Robert P. (1977). Timelessness and theological fatalism. Logique et Analyse, 20(80), pp. 475-490.

Pike, Nelson (1965). Divine omniscience and voluntary action. Philosophical Review, 74(1), 27-46.

Quinn, Philip L. (1978). Divine Foreknowledge and Divine Freedom. International Journal for Philosophy of Religion, 9(4), 219-240.

Ramberan, Osmond G. (1985). Omniscience, Foreknowledge and Human Freedom. Canadian Journal of Philosophy, 15(3), 483-488.

Taylor, Richard (1962). Fatalism. Philosophical Review, 71(1), 56-66.

Watts, Allan (1977). The Essential Allan Watts. Berkeley: CelestialArts.

Zagzebski, Linda (2013). Omniscience. In Chad Meister \& Paul Copan (eds.), The Routledge Companion to Philosophy of Religion (pp. 309-318). New York: Routledge. 
Fatalizam, predznanje i slobodna volja

Madhu Mangal Chaturvedi*

\section{Sažetak}

Ovaj rad iznosi tvrdnju da pojam božanskoga predznanja nije nedosljedan u odnosu na poricanje fatalizma. Iz ograničene perspektive nas ljudi moglo bi nam se učiniti da fatalizam nužno proistječe iz ideje sveznajućega Boga. Međutim, sa stajališta sveznajućega i svemogućega Boga - pretpostavimo u svrhu ove rasprave da takvo Biće postoji - božansko predznanje nužno ne implicira fatalizam. Nadalje, poricati da neki sveznajući Bog može biti u krivu o pitanju naše budućnosti znači iznijeti nedosljednu tvrdnju. Božansko predznanje znači da Bog ima nepogrješivo znanje o našoj budućnosti, a to mora biti fiksno. No, tvrdim da poricanje fatalizma nije nedosljedno u odnosu na Božje sveznanje kad se povezuje s još nekim njegovim atributima. Primjerice, spoj božanskoga predznanja, svemoći i slobodne volje. Drugim riječima, Bogu je poznata budućnost, ali on nije ograničen na spoznavanje iste budućnosti, jer Bog može htjeti budućnost koja se prilično razlikuje od one koju spoznaje. To znači, što se nas tiče, da je Božja slobodna volja dosljedna u odnosu na negaciju fatalizma. Posljednja tvrdnja implicira također da postoji prostor za ljudsku slobodnu volju između Božjega predznanja i njegove slobodne volje.

Ključne riječi: fatalizam; slobodna volja; božansko predznanje; sveznanje

* Doc. dr. sc. Madhu Mangal Chaturvedi, School of Philosophy \& Culture, Faculty of Humanities and Social Sciences, Shri Mata Vaishno Devi University. Adresa: Sub-Post Office Katra, Jammu and Kashmir (UT), India - 182320.E-adresa:vijai.madhu@smvdu.ac.in 